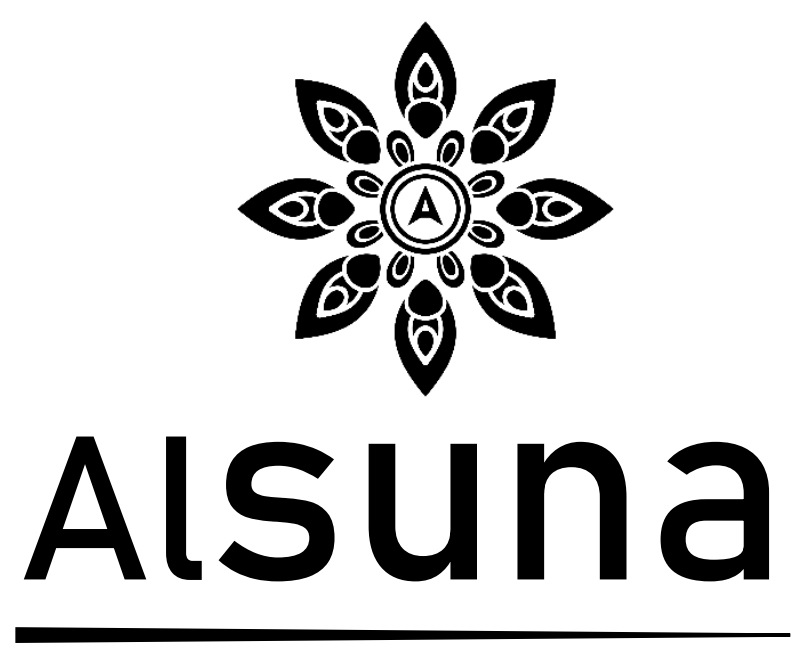

\title{
Journal of Arabic and Language
}

The focus and scope are to provide readers with a better understanding of Arabic and English Language present developments through the publication of articles. This journal includes research articles and brief communications, including:

Teaching Arabic-English as a Foreign Language.

Media Teaching Arabic and English.

Teaching Strategies of Arabic and English.

Technology Teaching Arabic and English.

Second Arabic-English Acquisition.

Arabic-English Modern Standard.

Linguistics, Literature, and History of Arabic-English.

Philosophy of Language.

The Language of The Holy Quran. 


\section{Alsuna}

Journal of Arabic and English Language

Vol. 4, no.1, 2021

\section{EDITOR-IN-CHIEF}

Ammar Zainuddin

INTERNATIONAL EDITORIAL BOARD

Yuli Ani Setyo Dewi

Saidna Zulfiqar Bin-Tahit

Eka Rizki Amalia

Azkia Muharom Albantani

Aliy Abdulwahid Adebisi

Najlaa Aly Matari

Nur Aeni

Nabila Boucharif

Bello Muhammad

\section{MANUSCRIPT EDITOR}

Hasyim Asy'ari

Nurul Azizah Ria Kusrini

Muhammad Mujtaba Mitra Zuana

Eva Lathifah Fauzia

Muqimah Liwais Sunnah

Mardhiana Jamal

\section{LAYOUT EDITOR}

Nafíul Huda

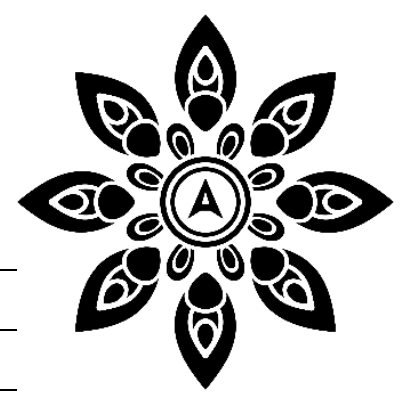

\section{Editorial Office:}

Alsuna: Journal of Arabic and English language,

Gedung A Fak. Tarbiyah Lantai I,

Rumah Jurnal Institut Pesantren KH. Abdul Chalim

J1. Raya Bendunganjati No I7,

Pacet, Mojokerto, Jawa Timur.

Phone: +62 32I6855722

E-mail: jurnal.alsuna@gmail.com

Website: https://e-journal.ikhac.ac.id/index.php/alsuna 


\title{
Reviewers Acknowledgement
}

The editors of Alsuna: Journal of Arabic and English Language gratefully acknowledge and appreciate the effort and generosity of our reviewers. The following people have contributed their time and expertise to provide constructive evaluation and feedback on reviewing our manuscripts.

\author{
Irene Rosalina \\ Universitas Negeri Surabaya \\ Cahya Edi Setyawan \\ STAI Masjid Syuhada Yogyakarta \\ Ade Destri Deviana \\ STIQ Amuntai
}

Muhammad Mujtaba Mitra Zuana

Institut Pesantren KH. Abdul Chalim

Lismay Leli

IAIN Bukittinggi

Rina Rachmawati

IKIP Widya Darma

Nahdliyyatul Azimah

Institut Pesantren KH. Abdul Chalim

Endang Munawar

STIDA Muhammadiyah

Niswatin Nurul Hidayati

IAI Al Hikmah Tuban

Ammar Zainuddin

Institut Pesantren KH. Abdul Chalim 


\section{Listener adapted Speech: How EFL Junior High School Students Adapt English Listening}

\section{Abstract}

Purpose - This study aims to determine whether the learning process with full English will be able to improve students' abilities in English skills more quickly.

Design/methodology/approach - This research method is a qualitative method with a case study approach. This research was conducted in Malang. Researchers used junior high school students from grades 7 to 9 who have the same case for sampling. The method of data collection is by observation and a questionnaire containing ten statements. Then the authors analyzed the data using data reduction patterns, data presentation, and verification/conclusions. After that, the authors tabulated the data so that they could be described easily.

Findings/result - The results of this study indicate that the use of full English in learning to listen to a procedural and a narrative text with gestures has positive opinions and perceptions from students, this also helps them find out some difficult vocabulary that is not yet known, helps students understand faster and last longer to remember vocabulary, besides that it also gives them the motivation to learn English.

Originality/value - Optimistic and innovative teachers, are the keys to student success in improving English comprehension by listening to full English.

Paper type - Research paper

\section{Muhamad Sofian Hadi}

Universitas Muhammadiyah Jakarta

Q 2 _ssofianhadi@yahoo.com

Lidiyatul Izzah

Universitas Muhammadiyah Jakarta 叉 lidiyatul.izzah@umj.ac.id

\section{Almira Faramadila \\ Universitas Muhammadiyah Jakarta \\ faramadila@gmail.com}

\section{Keywords:}

Listening Comprehension

English as Foreign Language

Listener Adapt

Article Information:

Submitted: 08 May, 2021

Accepted: 08 May, 2021

Approved: 03 July, 2021

\section{How to Cite}

Hadi, Muhamad, Lidiyatul Izzah, and Almira Faramadila. 2021. “Listener adapted Speech: How EFL Junior High School Students Adapt English Listening". Alsuna: Journal of Arabic and English Language 4 (1). https://doi.org/10.31538/alsuna.v4i1.1382.

\section{Introduction}

The first important thing that should be clear is that hearing and listening are two distinct meanings. Hearing occurs passively and involuntarily when sound is received through the ear; only at a glance or not have to be understood. Listening is voluntary or intentional 
Page $\mid 93$

and is an active process. There will be voting and directional attention to focus. Listening involves the desire to communicate and the ability to focus on specific sounds (Praxis 2014).

(Babita 2013) said, "the listening process takes place on The five stages of hearing, understanding or learning comprehension, remembering, evaluating and responding." You have to hear first before you can listen, but you don't have to listen in order to hear. Understanding, means understand the symbols we have seen and heard. We need to examine the meaning of what the stimuli we feel. Remembering means that a person not only accepts and clarifies messages, but also accepts to add to the brain's supply. Evaluating should allow active listeners to weigh evidence or classify facts from their opinions, and determine whether there is bias in the message, and to respond by asking recipients to complete a verbal or nonverbal feedback process.

(Hendar 2015) among the four language learning skills, listening is generally the most difficult. Most challenging, however, is neglected and takes less time in teaching compared to other language skills (such as reading, writing, and speaking). (Hadi, Muhamad, Lidiyatullzzah, n.d.) Especially for EFL students, they will find English is more challenging. Likewise, most research focuses more on writing and speaking skills. Nunan believes that listening is often seen as an increasingly important language skill, highlighting the need to acquire skills and strategies related to oral comprehension.

(Gilakjani and Sabouri 2016b); (Yıldırım, S., Yıldırım 2016); (Yulia and Lastri 2019); (Jafari, K., \& Hashim 2015) listening skills are very important in foreign language learning, because the key to language learning is receiving language input. Unfortunately, listening skills are often seen as passive skills in the classroom because students seem to sit quietly and listen to conversations.

Beside that, (Al-Nafisah 2019) guarantees that listening is an important means of learning a new language. Language learners are introduced to a new language primarily 
through listening, which is necessary and improves mastery of second language or foreign language skills.

If students cannot clearly understand what they are listening to in language class, they may find it difficult to learn the language, which may have a major impact on their learning of other communication skills (such as speaking, reading and writing). In addition, listening is essential for effective and meaningful participation in oral conversations. If students don't understand the dialogue, they will feel lost. This is why language learners lose confidence and keep asking for the repetition of spoken texts.

Likewise, Indonesian students are rarely used to listening to English speakers, making it difficult for them to understand spoken English at its usual tempo and tone. In addition, the students selected as the research topic all chose to listen as their preferred language learning skill. However, some people demonstrated strong reading skills and their adaptability to structured and alternative exercises.

(Azmi, B. M., Celik, B., Yidliz, N., \& Tugrul 2014); (Ghaderpanahi 2012); (Trismasari, Sudarsono, and Rosnjia 2016) The difficulty of listening in English can be caused by many factors, several of them are: accent, cultural difference, unfamiliar vocabulary, speed of listening.

(Renukadevi 2014) Listening strategies are activities or techniques that directly contribute to the recall of listening input. In recent years, various listening strategies have been developed to adapt to different listening situations, therefore, when teaching listening skills, language learners can adapt their listening behaviour to meet different situations, types of input and listening goals. The listening strategy is broadly classified as Top-down and Bottom-up strategy.

Bottom-up strategy, (Al-Nafisah 2019) According to the bottom-up model, listeners develop their perception and knowledge by starting to understand the smallest units of audio 
Page $\mid 95$

speech (which can be a single sound or phoneme). Then, they combine them into words to form phrases, clauses, and sentences. Finally, they add up these sentences meaningfully to get ideas and concepts. In this way, a meaningful relationship is established between them. This means that by adding up sound units, arranging them like building blocks, and forming them into terms, expressions, and sentences, listeners can compose and compile an inclusive and complete communication message.

Top-down strategy, this is a strategy that focuses on understanding the text as a whole. This clearly shows the main idea of the text. In addition, it enhances the learner's initial knowledge, thereby improving text comprehension. This strategy can be used with the help of listening activities, such as: completing sentences, identifying differences, identifying appropriate homophones, and role-playing and announcements. This activity can help students improve their listening skills, recognition, understanding, thinking and analysis (Pushpalata 2019).

All in all, in listening comprehension, bottom-up and top-down processing are used together to explain the intended meaning. In order to understand the information conveyed, the listener must understand the speech input, vocabulary and grammar (bottom-up processing), and adopt the context of situation, common sense and past experience (topdown processing). Therefore, it can be concluded that even if listening is a receiving technique, listening is not a passive behaviour, because the listener not only needs to understand the meaning of the message, but also needs to explain the speaker's expected meaning and acquire meaningfulness by absorbing the sound, information, words, and phrases. (Rahayu 2018).

(Gilakjani and Sabouri 2016a) The strategies to overcome the difficulties of listening in English are: Use familiar word when speaking to the students, usually students can be familiar if a speaker uses an American accent, not British. Very simple text can be provided for the 
Page $\mid 96$

listening process. Design listening tasks that can provoke the student interest. Body language or gesture and expression is the important thing to do by the speaker or teacher. It is best if students are given the opportunity to develop top-down and bottom-up processing skills because top-down activities provide motivation to discuss certain topics they already know, and bottom-up activities provide an understanding of language components such as words, grammar structure, sound, and intonation.

(Sholah 2010) Educational pathways are considered a suitable way to learn English since English is a foreign language for several countries. In Indonesia, this foreign language occupies a subject as a compulsory subject that must be learned by students, especially at the secondary school level. Talking about EFL (English as Foreign Language), (Andini et al. 2020) states that Indonesia, as one of the EFL (English as a Foreign Language) countries in the world, not many people communicate in English every day. Although more and more Indonesians are using English in their daily lives, many people believe that teaching English is a failure in this country. One reason for this failure is the absence of a unified national English education system.

This also has an impact on the use of English in everyday life. Indonesians do not consider English as important, let alone consider it a universal language. Therefore, they will react differently to English speakers. The reason is that regional languages are the native languages used by the majority of Indonesians because each region will have a different language. And everyone will use Indonesian as a second language or an alternative language.

Indonesians also have the stereotype that English speakers are more prestigious than those who speak other languages. Many people also believe that the culture of foreign language speakers can destroy or replace the habits of local or traditional languages. 
Page $\mid 97$

(Lorge, I., \& Katsos 2019) determined that the interlocutor matches their speech with a specific conversation partner. Even "baby talk", also called "mother tongue" is one of the most famous types of listener adaptations of "listener-adapted speech" (LAS for short).

Listener to speaker adaptation demonstrates the role of perceptual learning of speech in improving speech recognition. This greater clarity or adaptability can be achieved by increasing contact with the speaker. This is especially evident when the speaker's speech deviates from the norm due to a certain style, so that the listener will not be able to immediately understand the speaker. Several studies have been conducted, especially for perceptual learning of foreign accents. (Nowrouzi et al. 2015)

Many studies have produced evidence (mostly in understanding) that supports the hypothesis that bilinguals are more sensitive to listening the needs of their interlocutors. So in this study, it can be ascertained that it is likely that students who already have basic knowledge in English will be more sensitive to their interlocutor.

In addition, there are two adaptation processes that have been studied, speakerspecific adaptation and multi-speaker adaptation. It has been proven that when faced with a speaker with a certain language background, listeners will adapt to that single speaker. Adapting to a single speaker does not aid the clarity or classification of dialects of other speakers within the same speech community. However, it has been suggested that getting sufficient samples of different speech environments from a single speaker can actually be beneficial. This research considers these findings and aims to expand on how flexible the process of generalizing listeners is and to expand on previous research on listener adaptability.

\section{State of The Arts and Distinguish}

The study that relates to the listener adapted speech includes research conducted by Isabelle P. Lorge and Napoleon Katsos in 2019 from the University of Cambridge with the title 
Page $\mid 98$

"Listener-Adapted Speech: Bilinguals Adapt More" the study explains about This study examines bilingual adults and one language communicative skills through the production of two types of listener-adapted speech (LAS): speech for strangers and for children. Twenty bilingual adults and 20 monolinguals were asked to explain cooking recipes to a child, a native control adult and a non-native speaker adult. Participants adapted their speech for children and strangers compared to real adults. In addition, bilinguals adapt some of their speech features to a greater degree and in a well-tuned way (wider range of tones treating children and vocal hyper articulation aimed at strangers). The prevalence of these features in bilingual speech does not correlate with personality or cognitive measurement. They discuss the possible sources of differences in this talk of adaptation and implications for bilingual cognition theory.

\section{Method}

The researcher used a qualitative method that means after collecting, then clarifying the issue, analyzing, then interpreting the data to get the final result. This study employed the qualitative method with a case study approach. According to (Rahayu 2018), a Case study is a qualitative research method that studies individuals, groups or important examples to explain specific cases or provide useful generalizations. Therefore the case study approach allows the author to understand the effect of learning to use full English on students' listening ability listening using the procedure and narrative text.

This research results emphasize more on the data explanations found in the field. The results are not written in numbers and tables with statistical indicators, but in descriptive form, the resulting text, and presented in a narrative form. Observations, interviews, and questionnaires were selected as the researcher's data instrument collection. 
Page $\mid 99$

This research subject was 20 students from Junior High School student from grade VII, VIII, and IX whose lack of listening skill. Twenty learners need one meeting in two different tasks. In the first text, they will have listened to a speech from a speaker with full English, the second text mostly in Indonesian.

While analyzing the data, a researcher will use two techniques to collect data. The flow model is the first, and the second one is tabulating. Data analysis is a process that organizes data into certain categories, selects the most important topics to be studied, and systematically finds out and organizes data obtained from completed interviews, documents and field records from interviews. It is an understandable conclusion for readers or anyone else.

To build a flow model for analyzing data, it contains some components below (Matthew B. Miles, A. Michael Huberman 2018): Data reduction, Data display, Conclusion drawing, and verification.

The second technique in this research is tabulation. Tabulation is the process of placing data in the form of a table by making the table contain data based on analysis. The resulting table should be able to summarize all the data to be analyzed. The separation of tables will cause difficulties for researchers in the process of analyzing data.

The process that includes tabulation data is scoring and tabulation. The scoring process is to give a certain score in the questionnaire statement item, which is used to analyze the data from the query field or grade from 1 to 5 . The researcher derives the meaning of each of the following choices:

The next process is tabulating data. It means that the answers to the data are placed in a table, and the table will be based on frequency and percentage. Then all collected data will be selected and sorted. In this case, all the data collected by the researchers are quantitative data and have been converted to qualitative data to draw conclusions. 


\begin{tabular}{|c|c|c|}
\hline No. & Precentage & Interpretation \\
\hline 1. & $70 \%-99 \%$ & Almost \\
\hline 2. & $51 \%-69 \%$ & More than half \\
\hline 3. & $50 \%$ & Half \\
\hline 4. & $40 \%-49 \%$ & Almost half \\
\hline 5. & $1 \%-39 \%$ & Least \\
\hline
\end{tabular}

\section{Findings and Discussion}

The purpose of this research to find out the impact of improvement or development between teaching English using full English and teaching English using many Indonesian language on the listening skill of seventh to nineth grade student will be answered below.

The observation process takes 20 February - 27 February 2021. The researcher observed junior high school student in seventh to nineth grade. Each observation has approximately 30 minutes. This observation contains of three step:

For the procedure text, it contains of recipe. Students see the text and listen to what the English speaker is saying with full English and gestures with full english and gestures. While listening, students can give meaning to difficult words that they do not know the meaning of.

Than the second text is narrative, researcher will read it with english and directly translate it to bahasa for each sentence.

In the first text student were asked to guess what is the meaning of the difficult word that they underlined before, and answering the short question below about the text. The second text student was asked to write what the difficult word's meaning when the researcher said that meaning, then also answering the short questionnaire about the text.

Questionnaire, a total of 20 respondents received a questionnaire with ten questions. They should answer according to their own honesty. By using the Gutman scale, they will give a simple answer "yes" or "no" to the question item. According to the respondents' responses to the questionnaire, the researcher found the following result: 


\begin{tabular}{|c|c|c|c|c|c|c|c|}
\hline \multirow[t]{2}{*}{ No } & \multirow[t]{2}{*}{ Statement } & \multicolumn{5}{|c|}{ Alternative Answer ${ }^{1}$} & \multirow[t]{2}{*}{ Total } \\
\hline & & SA & A & $\mathbf{N}$ & DA & SDA & \\
\hline 1. & $\begin{array}{l}\text { I understand what I'm listening to in English } \\
\text { because the language is easy to understand }\end{array}$ & 7 & 9 & 4 & 0 & 0 & 20 \\
\hline 2. & $\begin{array}{l}\text { I remember new vocabulary words better } \\
\text { when using full English learning }\end{array}$ & 5 & 8 & 5 & 3 & 0 & 20 \\
\hline 3. & $\begin{array}{l}\text { I don't understand at all learning in full English } \\
\text { because I don't have basic knowledge }\end{array}$ & 1 & 1 & 5 & 7 & 6 & 20 \\
\hline 4. & $\begin{array}{l}\text { I am more interested if learning uses full } \\
\text { English }\end{array}$ & 4 & 6 & 7 & 3 & 0 & 20 \\
\hline 5. & $\begin{array}{l}\text { In my opinion, English is easy to understand } \\
\text { when using gestures }\end{array}$ & 11 & 7 & 2 & 0 & 0 & 20 \\
\hline 6. & $\begin{array}{l}\text { I feel learning becomes more fun when using } \\
\text { full English }\end{array}$ & 4 & 6 & 3 & 5 & 2 & 20 \\
\hline 7. & $\begin{array}{l}\text { I was confused and couldn't focus when } \\
\text { learning to use full English because it was too } \\
\text { fast }\end{array}$ & 1 & 2 & 2 & 7 & 8 & 20 \\
\hline 8. & $\begin{array}{l}\text { I think studying in full English will make me } \\
\text { even more clueless and won't make my grades } \\
\text { better }\end{array}$ & 0 & 2 & 6 & 7 & 5 & 20 \\
\hline 9. & $\begin{array}{l}\text { I agree with learning to use full English to } \\
\text { improve Listening skills faster }\end{array}$ & 5 & 7 & 5 & 3 & 0 & 20 \\
\hline 10. & $\begin{array}{l}\text { I don't think learning full English has a good } \\
\text { impact on improving my listening skills }\end{array}$ & 0 & 2 & 3 & 9 & 6 & 20 \\
\hline
\end{tabular}

Table 2: Respondents' Responses to The Questionnaire

The data collected from the questionnaire will be provided by descriptive analysis statistics using the following formula:

The purpose of the above data processing is to give a detailed description. In order to make it easier to analyze the data in the questionnaire, the following are the table data in the questionnaire and the detailed description in the table.

\begin{tabular}{|c|c|c|c|c|c|c|c|}
\hline \multirow[t]{2}{*}{ No } & \multirow[t]{2}{*}{ Statement } & \multicolumn{5}{|c|}{ Alternative Answer ${ }^{2}$} & \multirow[t]{2}{*}{ Total } \\
\hline & & SA & A & $\mathbf{N}$ & DA & SDA & \\
\hline 1. & $\begin{array}{l}\text { I understand what I'm listening to in English } \\
\text { because the language is easy to understand }\end{array}$ & $35 \%$ & $45 \%$ & $20 \%$ & $0 \%$ & $0 \%$ & $100 \%$ \\
\hline 2. & $\begin{array}{l}\text { I remember new vocabulary words better when } \\
\text { using full English learning }\end{array}$ & $25 \%$ & $40 \%$ & $25 \%$ & $15 \%$ & $0 \%$ & $100 \%$ \\
\hline
\end{tabular}

\footnotetext{
${ }^{1}$ Alternative Answer: 1) SA: Strongly Agree, 2)DA : Disagree, 3) A : Agree, 4) SDA : Strongly Disagree, 5) N : Neutral

${ }^{2}$ Alternative Answer: 1) SA: Strongly Agree, 2)DA : Disagree, 3) A : Agree, 4) SDA : Strongly Disagree, 5) N : Neutral
} 


\begin{tabular}{|c|c|c|c|c|c|c|c|}
\hline 3. & $\begin{array}{l}\text { I don't understand at all learning in full English } \\
\text { because I don't have basic knowledge }\end{array}$ & $5 \%$ & $5 \%$ & $25 \%$ & $35 \%$ & $30 \%$ & $100 \%$ \\
\hline 4. & I am more interested if learning uses full English & $20 \%$ & $30 \%$ & $35 \%$ & $15 \%$ & $0 \%$ & $100 \%$ \\
\hline 5. & $\begin{array}{l}\text { In my opinion, English is easy to understand } \\
\text { when using gestures }\end{array}$ & $55 \%$ & $35 \%$ & $10 \%$ & $0 \%$ & $0 \%$ & $100 \%$ \\
\hline 6. & $\begin{array}{l}\text { I feel learning becomes more fun when using full } \\
\text { English }\end{array}$ & $20 \%$ & $30 \%$ & $15 \%$ & $25 \%$ & $10 \%$ & $100 \%$ \\
\hline 7. & $\begin{array}{l}\text { I was confused and couldn't focus when learning } \\
\text { to use full English because it was too fast }\end{array}$ & $5 \%$ & $10 \%$ & $10 \%$ & $35 \%$ & $40 \%$ & $100 \%$ \\
\hline 8. & $\begin{array}{l}\text { I think studying in full English will make me even } \\
\text { more clueless and won't make my grades better }\end{array}$ & $0 \%$ & $10 \%$ & $30 \%$ & $35 \%$ & $25 \%$ & $100 \%$ \\
\hline 9. & $\begin{array}{l}\text { I agree with learning to use full English to } \\
\text { improve Listening skills faster }\end{array}$ & $25 \%$ & $35 \%$ & $25 \%$ & $15 \%$ & $0 \%$ & $100 \%$ \\
\hline 10. & $\begin{array}{l}\text { I don't think learning full English has a good } \\
\text { impact on improving my listening skills }\end{array}$ & $0 \%$ & $10 \%$ & $15 \%$ & $45 \%$ & $30 \%$ & $100 \%$ \\
\hline
\end{tabular}

Table 3: Questionnaire and The Detailed Description

The table above prove that the percentage of students' response frequency. It can be said that point 1 show (35\%) of students state with strongly agree that they understand what they was listening to in English because the language of speaker is easy to understand. Nearly half of the students (45\%) said that the speaker speaks is easy to understand, while the small group expressed hesitation (20\%), and there was no student show did not agree and also strongly disagree with the first statement.

In addition, the second point shows that a small percentage of students (35\%) said that they strongly agree that they remember new vocabulary words better when using full English learning. (30\%) agree, (25\%) of students answered doubtfully, the mostsmall group states are disagree (15\%), and no one state disagree, also strongly disagree (0\%).

Therefore, it can be concluded that if they agree that the speakers speak is easily to understand and remember.

The third point prove that (5\%) of students admit that they did not understand at all learning in full English because they don't have basic knowledge. A small percentage of 
students agreed (5\%) and hesitated (25\%). (35\%) of the student states disagree and strongly disagree (30\%). That means, mostly of the students already have the basic English knowledge.

Point 4 shows the percentage of students (20\%) strongly agree that they more interested if learning uses full English. Another part of the students agreed (25\%) and hesitated (20\%). Most other big states disagree (35\%) and strongly disagree (0\%). It indicates that they do not have a problem with full English is used in the learning process, but they would prefer if Indonesian is still used because they do not want to or even afraid to get out of their comfort zone so far.

At the same time, fifth statement pointed out more than half of students (55\%) said that in their opinion, English is easy to understand when using gestures, they found it helpful to understand the procedure text. (35\%) of the students agreed. A small number of 20 statements expressed hesitation (10\%), and no one expressed disagree and strong disagreement (0\%). Therefore, it can be concluded that they almost unanimously agree that English is easy to understand when using gestures.

Meanwhile, the sixth point, it indicates (25\%) percentage of students feel learning becomes more fun when using full English, more (30\%) of the students agreed. Other small groups expressed hesitation (15\%). But there are students who disagree (25\%), and a small percentage of students are strongly disagreeing (10\%). Therefore, it can be concluded that more than half of students agree but not a few also disagree with this statement.

Then, point seven states that a small number of students (5\%) said that they was confused and could not focus when learning to use full English because it was too fast, and another small student agreed (10\%), also (10\%) expressed hesitation. They state disagree (35\%), and a big group of students expressed strong disagreement (40\%). That means, they was not confused enough and focus easily when the speaker speaks slowly. 
In addition, statement number 8 pointed out that no one said they firmly agreed that studying in full English will make me even more clueless and would not make their grades better $(0 \%)$, and small groups of the students agreed (10\%). Bigger groups expressed hesitation (30\%), also disagree (30\%), and expressed strong disagreement (30\%). The data shows there are still a few students who feel that studying in full English will make me even more clueless and would not make their grades better.

Then, point 9 prove that (25\%) of students said they strongly agreed with learning to use full English to improve Listening skills faster, and a biggergroups agreed (30\%). Others expressed hesitation (30\%). Small groups disagree (15\%), and no one expressed strong disagreement (0\%). Therefore, it can be concluded that if they agree to use full English to improve Listening skills faster.

In the last statement, it indicates that no one of students (0\%) strongly agree that learning with full English do not has a good impact on improving their listening skills, but a small groups are agree (10\%). (15\%) of students states hesitate. Mostly students are disagree (45\%), and (30\%) states strongly disagrees. Students feel that learning with full English of course having a good impact, but small groups of them do not feel the same.

Qualitative interviews, not unlike surveys, attempt to collect data by asking questions to the object of research (Piergiorgio Corbetta 2003). This interview is used to support the answers to the questionnaire answered by learners to find out information from students about their abilities and interests in learning full English, whether their memory is better when they listen to teachers who use full English in learning or not. Interview consists of seven questions. fourteen out of twenty learners had positive perceptions of use full English in learning. They consider that use full English in learning comprehension listening to text can make the class interesting out of curiosity, not boring, and fun. 
Their expressed their interest like, "kalo teks yang langsung diterjemahin ke Bahasa

\begin{tabular}{|c|c|c|c|c|}
\hline No & Statement & Analysis Result & $\mathbf{P}(\%)$ & Interpretation \\
\hline 1. & $\begin{array}{l}\text { Speaker speaks in English is easy to listen and } \\
\text { understand }\end{array}$ & Agree & $45 \%$ & Almost half \\
\hline 2. & $\begin{array}{l}\text { New vocabulary is easier to remember when } \\
\text { learning using full English }\end{array}$ & Agree & $40 \%$ & Almost half \\
\hline 3. & $\begin{array}{l}\text { Difficult to listen and understand English } \\
\text { because have not basic knowledge }\end{array}$ & Disagree & $35 \%$ & Least \\
\hline 4. & Interest in learning using full English & Hesitant & $35 \%$ & Least \\
\hline 5. & Gesture makes listening in English easier & Strongly Agree & $55 \%$ & More than half \\
\hline 6. & $\begin{array}{l}\text { Learning is more exciting when using full } \\
\text { english }\end{array}$ & Agree & $30 \%$ & Least \\
\hline 7. & $\begin{array}{l}\text { The speaker speaks too fast making it difficult } \\
\text { to understand }\end{array}$ & Strongly Disagree & $40 \%$ & Almost half \\
\hline 8. & $\begin{array}{l}\text { Learning with full English will not increase the } \\
\text { score and comprehension }\end{array}$ & Disagree & $35 \%$ & Least \\
\hline 9. & $\begin{array}{l}\text { Learning using full English will improve } \\
\text { listening skills faster }\end{array}$ & Agree & $35 \%$ & Least \\
\hline 10. & $\begin{array}{l}\text { Learning using full English has not a good } \\
\text { impact on improving listening skills }\end{array}$ & Disagree & $45 \%$ & Almost half \\
\hline
\end{tabular}

Indonesia itu seringnya kita ngeremehin karena gaada tantangan, jadi gampang lupa. Kalau full Bahasa Inggris kan clue-nya cuma pakai gesture, jadi lebih susah ditebak dan bikin lebih lama inget waktu tau artinya, karena dapet artinya kan gak mudah tuh, jadi kita inget terus dan ketambahan dari gesture-nya juga."

Another student also said, "kan biasanya kalau pelajaran listening gitu kita cuma disuruh duduk dan mendengarkan aja (passive), kalau pakai gesture rasanya lebih seru karena seperti main tebak kata."

Other data respondents, namely six out of twenty students perceive the use of full English in learning negatively. They are not happy when the procedural text that they listened to in full English, they preferred to listen to the narrative text read directly with the Indonesian translation. One of them said "susah mengertinya, saya gak bisa Bahasa Inggris. Mending pakai Bahasa Indonesia aja." 
They also arguming that learning using full English makes them difficult to focus and bored. The students' negative statements above indicate that full English learning will be more interesting if the students being taught have interest or basic skills in English.

Observation and questionnaire survey results show that the number of respondents who are proficient in spoken language is even higher than those in the fair category.

If we convert the result to percentage, then we will find in the table below.

Based on the table of analysis result above, there are 10 components will be discussed. The researcher compares this study with previous findings, it turns out that the findings obtained are same result from Lorge \& Katsos (2019), in their research they found that students who initially have basic knowledge of English have the advantage of better communicative skills (in the sense of sensitivity to the interlocutor's perspective and efforts directed at improving and communication).

In this study, listening skills is the main topic. Based on the research above, the researcher extend to modify the research previously carried out for ESL countries and to enrich the similar research. The study focused on observing students' abilities in English listening knowledge of junior high school students.

Data obtained from observations and questionnaires with 20 junior high school students from grades seven to nine, the researcher found several techniques that can be used by teachers in improving students' listening skills using full English. Initially it must be difficult because students in EFL countries are not used to it, but with gestures, pictures, or videos that support it, visual and audio support makes it easier for students to understand, if it's like that, students will find it easier to remember words and meanings in English. 


\section{Conclusion}

Based on research conducted on 20 junior high school students from grades seven to nine, it can be concluded that learning using full English is quite effective in improving Page | 107 students' listening skills. However, with only one to two meetings, EFL students will certainly not see a significant change, because they are not used to it.

There were two meetings conducted to get the results, the first was the observation about 30 minutes of each students, then a week after that was the questionnaire. The results from the data analysis can be summarized as below:

Students feel that learning full English with visual and audio aids, for example using gestures accompanied by the teacher reading the text, makes learning more exciting and easier to remember vocabulary and meanings in English.

Many students are still hesitant to learn using full English, they are still afraid of not understanding and being unfamiliar with it. Because they have always been accustomed to hearing Indonesian even though their subjects are English.

Mostly of them already have basic English skills, so they don't have much trouble hearing learners in full English as long as the language is easy to understand. The majority of them have the same opinion to disagree with the statement that learning using full English will not increase their understanding, knowledge, and score. For those who do not have basic knowledge it may be difficult, because they are not used to it.

\section{Implications of Findings}

Previously reported findings indicated that students' listening skills improved. The implications of the action described as follows: First, the use of full English in learning English lesson helps them to improve their basic English skills especially their listening skills which is the topic of this research. Second, the use of full English in learning English lesson brings a goodeffects on interest and enthusiasm students especially with gesture or a creative visual. 
Third, the use full English in learning English lesson makes the teachers and students will be more aware that they are able to do full English learning, they just need to get used to it.

\section{Bibliography}

Al-Nafisah, Khalid I. 2019. 'Issues and Strategies in Improving Listening Comprehension in a Classroom'. International Journal of Linguistics $11 \quad$ (3): 93. https://doi.org/10.5296/ijl.v11i3.14614.

Andini, Tresna Nur, Lee Ye Eun, Alina Khramova, and Alicja Żok. 2020. 'ELT Comparison: Increasing Students Speaking Ability in Indonesia, South Korea, Russia, and Poland'. English Language in Focus (ELIF) 2 (2): 131. https://doi.org/10.24853/elif.2.2.131-140.

Azmi, B. M., Celik, B., Yidliz, N., \& Tugrul, M. C. 2014. 'Listening Comprehension Difficulties Encountered by Students in Second Language Learning Class.' Journal of Educational and Instructional Studies in the World 4 (4): 1-6.

Babita, Tyagi. 2013. 'Listening : An Important Skill and Its Various Aspects'. The Criterion : An International Journal in English, no. 12: 1-8.

Ghaderpanahi, L. 2012. 'Using Authentic Aural Materials to Develop Listening Comprehension in the EFL Classroom.' English Language Teaching 5 (6): 146-53.

Gilakjani, Abbas Pourhosein, and Narjes Banou Sabouri. 2016a. 'Learners' Listening Comprehension Difficulties in English Language Learning: A Literature Review'. English Language Teaching 9 (6): 123. https://doi.org/10.5539/elt.v9n6p123.

- - . 2016b. 'The Significance of Listening Comprehension in English Language Teaching'. Theory and Practice in Language Studies 6 (8): 1670. https://doi.org/10.17507/tpls.0608.22.

Hadi, Muhamad, Lidiyatullzzah, and Aulia Maharani. n.d. 'Journal of Arabic and Language'. Hendar. 2015. 'Implementing Nunan's Autonomous Language Learning Model ( Nallm ) To EFL Students of Widyatama University'. TEACHING AND LEARNING IN THE 21ST CENTURY: Challenges for Lecturers and Teachers., 114-22.

Jafari, K., \& Hashim, F. 2015. 'A Comparison of Normal and Moderately Slow Speech Rates: Listening to Students Voices in Listening Comprehension Classes in EFL Context.' International Journal of Foreign Language Teaching in the Islamic World (FLTJ) 3 (3): $5-11$. 
Lorge, I., \& Katsos, N. 2019. 'Listener Adapted Speech: Bilinguals Adapt in a More Sensitive Way.' Linguistics Approaches to Bilingualism. 9 (3): 376-97. https://doi.org/10.1075/lab.16054.lor.

Matthew B. Miles, A. Michael Huberman, Johnny Saldana. 2018. Qualitative Data Analysis: A Methods Sourcebook. SAGE Publications. Vol. 4. SAGE Publications.

Nowrouzi, Sara, Shu Sim Tam, Gholamreza Zareian, and Vahid Nimehchisalem. 2015. 'Iranian EFL Students' Listening Comprehension Problems'. Theory and Practice in Language Studies 5 (2): 263. https://doi.org/10.17507/tpls.0502.05.

Piergiorgio Corbetta. 2003. The Qualitative Interview In: Social Research: Theory, Methods and Techniques. https://dx.doi.org/10.4135/9781849209922.n10.

Praxis, Therapy I N. 2014. 'THERAPY IN PRAXIS Therapeutic Listening ${ }^{\circledR \prime}$, 1-6.

Pushpalata. 2019. 'Language in India' 19 (1): 198-202.

Rahayu, Chyntia. 2018. 'Students' Perception of Using Animation Video Faculty of Educational Sciences', 118.

Renukadevi, D. 2014. 'The Role of Listening in Language Acquisition; the Challenges \& Strategies in Teaching Listening.' International Journal of Education and Information Studies. 4 (1): 59-63.

Sholah, Hanif Maulaniam. 2010. 'Enhancing EFL Learners' Writing Skill via Journal Writing'. Alsuna: Journal of Arabic and Language 3 (3): 96-116. https://doi.org/10.5539/elt.v3n3p81.

Trismasari, Meilisa, Sudarsono, and Eni Rosnjia. 2016. 'Factors Influencing English Listening Difficulties'. Jurnal Pendidikan Dan Pembelajaran Khatulistiwa 5 (12): 1-12.

Yıldırım, S., Yıldırım, Ö. 2016. 'The Importance of Listening to Language Learning and Listening Comprehension Problems Experienced by Language Learners: A Literature Review.' Abant İzet Baysal Üniversitesi Eğitim Fakültesi Dergisi 16 (4): 2097.

Yulia, Henny, and Neti Lastri. 2019. 'An Investigation of Listening Comprehension Problems Encountered By Third Semester Students of English Education Study Program At Baturaja University'. Edukasi Lingua Sastra 17 (1): 55-71. https://doi.org/10.47637/elsa.v17i1.106. 